\title{
SILICON FERTILIZATION AND SEED MICROBIOLIZATION ON DISEASE SEVERITY AND AGRONOMIC PERFORMANCE OF UPLAND RICE ${ }^{1}$
}

\author{
IVANEIDE DE OLIVEIRA NASCIMENTO ${ }^{2 *}$, ANTÔNIA ALICE COSTA RODRIGUES ${ }^{3}$, HEDER BRAUN $^{3}$, CEALIA \\ CRISTINE SANTOS ${ }^{3}$, ARICLÉIA DE MORAES CATARINO ${ }^{4}$
}

\begin{abstract}
Rice is one of the world's most consumed cereals, however, its production is affected by fungal diseases. Thus, the objective of this work was to evaluate the severity of diseases and grain yield potential of upland rice with silicon fertilization combined with seed microbiolization with Bacillus methylotrophicus isolates. Two experiments were conducted, one in Igarapé do Meio, Maranhão (MA), Brazil, with rice seeds of the variety Palha-Murcha and one in São Bento MA with rice seeds of the variety BRS-Primavera. A randomized block experimental design in a split-plot arrangement with five replications were used in both experiments, with agro-silicon rates $\left(0.0,1.0,2.0,4.0\right.$ and $\left.6.0 \mathrm{Mg} \mathrm{ha}^{-1}\right)$ in the plots and microbiolized and nonmicrobiolized rice seeds with B. Methylotrophicus at concentration of $10^{8} \mathrm{CFU} \mathrm{ml^{-1 }}$ in the subplots. The seedling emergence, grain yield, number of panicles, plant height, plant dry weight and severity of brown leafspot, leaf scald and grain spot were evaluated. Soil fertilization with agro-silicon affected positively the plant height of the variety Palha-Murcha and the number of panicles, plant dry weight and grain yield of the variety BRS-Primavera, and negatively the germination of the variety BRS-Primavera. Leaf scald severity in the variety $B R S$-Primavera reduced with microbiolized seeds with $B$. methylotropicus. Microbiolization with $B$. methylotropicus had no effect on severity of brown leafspot and grain spot in the varieties evaluated.
\end{abstract}

Keywords: Bacillus methylotrophicus. Agrosilicon. Biological control. Diseases. Rice production.

\section{EFEITO DA FERTILIZAÇÃO DE SILÍCIO E MICROBIOLIZAÇÃO DE SEMENTES SOBRE A SEVERIDADE DE DOENÇAS E DESEMPENHO AGRONÔMICO DE ARROZ DE SEQUEIRO}

RESUMO - O arroz é um dos cereais mais consumidos em todo o mundo e sua produção é afetada por doenças fúngicas. Neste sentido objetivou-se avaliar a severidade de doenças e o potencial produtivo do arroz de terras altas em função da aplicação de silício e sementes microbiolizadas com isolados de Bacillus methylotrophicus. Foram realizados dois experimentos, em dois munícipios do estado do Maranhão, Brasil: um em Igarapé do Meio, com sementes de arroz da variedade Palha Murcha e outro em São Bento, com a variedade Primavera. Os experimentos foram instalados no delineamento em blocos casualizados, com cinco repetições, em parcelas subdivididas. As parcelas foram constituídas por cinco doses de agrosilício $\left(0,0 ; 1,0 ; 2,0 ; 4,0\right.$ e 6,0 t ha $\left.{ }^{-1}\right)$ e as subparcelas foram constituídas por sementes de arroz microbiolizadas e não microbiolizadas com $B$. methylotrophicus, na concentração de $10^{8} \mathrm{UFC} \mathrm{ml}^{-1}$. Os parâmetros avaliados foram emergência de plântulas, produtividade de grãos, número de panícula, altura de planta, massa de planta seca e severidade de mancha parda, escaldadura e mancha de grãos. As doses de agrosilício aplicadas no solo afetaram positivamente a altura de plantas, para a variedade Palha Murcha. Na variedade Primavera, as doses de agrosilício influenciaram de forma positiva o número de panículas, massa de planta seca e a produtividade de grãos e de forma negativa a germinação. Para esta variedade, a severidade da escaldadura foi reduzida quando as sementes foram microbiolizadas com $B$. methylotropicus. A microbiolização com B. methylotropicus não influenciou a severidade da mancha parda e a severidade da mancha de grãos, para as duas variedades de arroz.

Palavras-chave: Bacillus methylotrophicus. Agrosilício. Controle biológico. Doenças. Produção de arroz.

\footnotetext{
${ }^{*}$ Corresponding author

${ }^{1}$ Received for publication in $08 / 25 / 2016$; accepted in $04 / 10 / 2017$.

Paper extracted from the doctoral thesis of the first author.

${ }^{2}$ Center of Exact, Natural and Technology Sciences, Universidade Estadual da Região Tocantina do Maranhão, Imperatriz, MA, Brazil; ivaneide_agro@yahoo.com.br.

${ }^{3}$ Universidade Estadual do Maranhão, São Luís, MA, Brazil; aacrodrigues@outlook.com, hederbraun@gmail.com, cealia@hotmail.com.

${ }^{4}$ Instituto Nacional de Pesquisas da Amazônia, Manaus, AM, Brazil; amoraescatarino@gmail.com.
} 


\section{INTRODUCTION}

Genetically improved rice varieties have grain yield potential of $10 \mathrm{Mg} \mathrm{ha}^{-1}$, however, their world average grain yield is $5 \mathrm{Mg} \mathrm{ha}^{-1}$, which denotes the need for reduce this difference in grain yield observed in the field. This difference is due mainly to biotic and abiotic stresses that affect rice crops (KHUSH; JENA, 2008). Fungal diseases are among this biotic factors, affecting the rice grain quality and yield.

Various fungal diseases affect upland rice, such as the leaf blast (Pyricularia oryzae Cav.), leaf scald (Monographella albescens Thume), brown leafspot (Helminthosporium oryzae Breda de Haan), grain spot (Phoma spp., Drechslera oryzae Breda de Haan, Curvularia lunata (Wakker) Boedijn, Nigrospora oryzae (Berk. \& Broome), Alternaria spp. and Fusarium spp.) and narrow brown leafspot (Cercospora oryzae Miyake) (UTUMI, 2008). Leaf scald symptoms begin in the apical parts or blade edges of the leaves, with olive-green coloration. Brown leafspot symptoms occur in leaves, grains, coleoptile, panicle branches and sheath, showing reddish-brown oval spots, with gray center. Grain spot symptoms are variable, depending on the pathogen, infection stage and climatic conditions. These diseases are affected by environmental conditions, plant density, dew (SANTOS; SANTIAGO, 2014) and plant nutritional imbalance (SANTOS et al., 2010). The diseases leaf scald, brown leafspot and grain spot, evaluated in the present work, occur in crops in the State of Maranhão, Brazil.

Silicon fertilization as phytosanitary control of diseases are of interest to researchers and society, since it reduces applications of fungicides, improves growth, development and architecture and strengthens cell wall of plants (GOMES et al., 2011). Moreover, it reduces cuticular transpiration, increases photosynthetic efficiency, resistance to pest and pathogens and tolerance to drought of plants and promotes formation of compounds such as phenols (MENDONÇA et al., 2013). It also potentiates activities of enzymes such as peroxidases, polyphenoloxidases and quintinases (GOMES et al., 2008), increases the action of antioxidative defenses, reduces oxidative damage of functional molecules in membranes and increases stomatal resistance (GUNES et al., 2007; CRUSCIOL et al., 2009).

Silicon fertilization may affect rice grain yield, control or reduce diseases such as brown leafspot (SANTOS et al., 2011) and reduce leaf blast severity in leaves and panicles (FILIPPI et al., 2012). The reduction of disease severity is due to the absorbed silicon deposited below the cuticle, which forms a double layer silica-cuticle (SANGSTER; HODSON; TUBB, 2001).

Bacillus methylotrophicus is a gram-positive bacterium that interacts well with plants, has high guanine and low cytokinins contents, excellent effect for disease biological control, plant growth promotion and bioremediation, and produces bacteriocins, which makes its use as a plant protection agent a potential alternative for disease control (TUMBARSKI; PETKOV; DENKOVA, 2015).

Rice seeds microbiolization with Pseudomonas fluorescens (Flugge) Migula, Bacillus subtilis (Cohn), Bacillus spp. and Stenotrophomonas malthophilia (Swings) is considered an efficient treatment to control Rhizoctonia solani Kuhn, due to the ability of these fungi to control this pathogen and the possibility of make them more efficient by combining them with compounds to stimulate their activity (LUDWIG; MOURA, 2007).

The hypothesis considered in this work is that silicon fertilization combined with the seed microbiolization with $B$. methylotrophicus reduces the difference between the grain yield potential and observed in the field, by reducing the plant susceptibility to pathogens in rice crops.

Thus, the objective of this work was to evaluate the severity of diseases and grain yield potential of upland rice with silicon fertilization combined with seed microbiolization with $B$. methylotrophicus isolates.

\section{MATERIAL AND METHODS}

Two experiments were conducted in rice fields with history of leaf blast, leaf scald, brown leafspot and grain spot; one in the rural settlement Diamante Negro, Jutaí, Igarapé do Meio, State of Maranhão, Brazil $\left(03^{\circ} 35^{\prime} 9^{\prime \prime} \mathrm{N}, 45^{\circ} 09^{\prime} 50.6^{\prime \prime} \mathrm{W}\right.$ and $9 \mathrm{~m}$ of altitude) in the 2013-2014 crop season, and one in the School Farm of the Maranhão State University, São Bento, State of Maranhão, Brazil (2 $2^{\circ} 42^{\prime} 15,6^{\prime \prime} \mathrm{N}$, $44^{\circ} 51^{\prime} 19,6^{\prime \prime} \mathrm{W}$ and $2 \mathrm{~m}$ of altitude) in the 2014-2015 crop season.

The rice variety Palha-Murcha (Creole) was planted in Igarapé do Meio and the variety BRS-Primavera (improved) in São Bento. The variety BRS-Primavera is indicated for areas of low to moderate fertility, due to its tendency to lodging in areas of high fertility, reaching grain yields of up to $3,550 \mathrm{~kg} \mathrm{ha}^{-1}$, and is considered moderately resistant to the diseases brown leafspot and grain spot (EMBRAPA, 2014). The average temperature of the two experimental areas was $31.7^{\circ} \mathrm{C}$ and their mean precipitation was $218 \mathrm{~mm}$ (Meteorology Laboratory of the Geo-Environmental Center of the Maranhão State University).

The soils of the experimental areas were collected to evaluate their silicon content and determine their chemical and physical characteristics. The soils of the experimental areas Igarapé do Meio and São Bento had respectively 
sandy loam and loamy sand texture, 27 and $10 \mathrm{~g} \mathrm{dm}^{-3}$ of organic matter, $\mathrm{pH}$ based on $\mathrm{CaCl}_{2}$ of 4.3 and $4.3,4.3$ and $4.0 \mathrm{mg} \mathrm{dm}{ }^{-3}$ of $\mathrm{P}, 3.7$ and $3.5 \mathrm{mmol}_{\mathrm{c}} \mathrm{dm}^{-3}$ of $\mathrm{K}^{+}, 37$ and $12 \mathrm{mmol}_{\mathrm{c}} \mathrm{dm}^{-3}$ of $\mathrm{Ca}^{2+}$, 22 and $10 \mathrm{mmol}_{\mathrm{c}} \mathrm{dm}^{-3}$ of $\mathrm{Mg}^{2+}, 42$ and $23 \mathrm{mmol}_{\mathrm{c}} \mathrm{dm}^{-3}$ of $\mathrm{H}^{+}+\mathrm{Al}^{3+}, \quad 69.4$ and $25.5 \mathrm{mmol}_{\mathrm{c}} \mathrm{dm}^{-3}$ of sum of bases, 111.4 and $48.5 \mathrm{mmol}_{\mathrm{c}} \mathrm{dm}^{-3}$ of cation exchange capacity, $62.5 \%$ and $53 \%$ of base saturation and 5.9 and $1.5 \mathrm{mg} \mathrm{dm}^{-3}$ of silicon.

Silicon fertilization with agro-silicon (25\% $\mathrm{Ca}, 6 \% \mathrm{Mg}$ and $10.5 \% \mathrm{Si}$ ) and liming with dolomitic limestone $(32 \% \mathrm{CaO}, 15 \% \mathrm{MgO}$, total neutralizing power of $90 \%$ ) were performed 60 days before the rice planting. The agro-silicon applied $\left(6.0 \mathrm{Mg} \mathrm{ha}^{-1}\right)$ contained $1,500 \mathrm{~kg} \mathrm{ha}^{-1}$ of $\mathrm{Ca}$ and $360 \mathrm{~kg} \mathrm{ha}^{-1}$ of Mg, according to its $\mathrm{Ca}, \mathrm{Mg}$ and $\mathrm{Si}$ contents. Dolomitic limestone was applied to balance $\mathrm{Ca}$ and $\mathrm{Mg}$ contents of the experimental units, thus isolating the effect of the silicon released by the agro-silicon, since both the limestone and agro-silicon are used as sources of $\mathrm{Ca}$ and $\mathrm{Mg}$.

A randomized block experimental design in a split-plot arrangement with five replications were used in both experiments, with agro-silicon rates $\left(0.0,1.0,2.0,4.0\right.$ and $\left.6.0 \mathrm{Mg} \mathrm{ha}^{-1}\right)$ applied 60 days before planting in the plots and microbiolized and non-microbiolized rice seeds with Bacillus Methylotrophicus (isolates B12 and B41) in the subplots.

The plots had area of $6.0 \mathrm{~m} \times 4.5 \mathrm{~m}$ and the subplot had area of $6.0 \mathrm{~m} \times 2.25 \mathrm{~m}$. The two rice varieties were grown in the upland rice system, with spacing of $0.45 \mathrm{~m}$ between rows, and 360,000 plants $\mathrm{ha}^{-1}$. The evaluation area of the subplots was $2.7 \mathrm{~m}^{2}$, discarding the two lateral rows and the borders $(2.0 \mathrm{~m}$ of each end of the central rows).

The isolates of B. methylotrophicus (B12 and B41) used for the rice seed microbiolization with molecular identification are part of the biological collection of the Phytopathology Laboratory of the Maranhão State University, registered as MGSS-214 and MGSS-215, respectively, which have proved antimicrobial activity in other pathological systems. These isolates were evaluated in vitro and inhibited mycelial growth of Magnaporthe oryzae (NASCIMENTO et al., 2016).

These B. methylotrophicus isolates were multiplied in culture medium (PDA) and maintained in a BOD chamber for growth for 48 hours at $28^{\circ} \mathrm{C}$ and 12-hour photoperiod. Then, bacterial suspensions were prepared with these isolates, adjusting their concentrations to $10^{8} \mathrm{UFC} \mathrm{ml}^{-1}$ in a spectrophotometer (wavelength of $540 \mathrm{~nm}$ and absorbance of 0.5 ). The two isolates were mixed, using $1000 \mathrm{~mL}$ of the B12 and B41 inocula. Seeds of the two rice varieties were immersed for 24 hours under constant stirring at $50 \mathrm{rpm}$ in this mix.

Manual and mechanical weeding were performed in the experimental area of Igarapé do Meio before planting, and manual weeding were performed throughout the experimental periods.

Soil fertilization at planting consisted of $200 \mathrm{~kg} \mathrm{ha}^{-1}$ of 5-30-10 (N-P-K) (Iguarapé do Meio) and $200 \mathrm{~kg} \mathrm{ha}^{-1}$ of 5-30-15 (N-P-K) (São Bento), based on the soil chemical analysis and commercial formulations locally available. Rice plants of the variety BRS-Primavera (São Bento) were fertilized with $91 \mathrm{~kg} \mathrm{ha}^{-1}$ of urea $(45 \%$ of N) 40 days after emergence due to nitrogen deficiency symptoms in the plants. Rice plants of the variety Palha-Murcha (Igarapé do Meio) showed no symptoms of nitrogen deficiency.

The number of emergent seedlings was manually counted at the $5^{\text {th }}, 10^{\text {th }}$ and $15^{\text {th }}$ day after planting. Ten plants per subplot of the variety $B R S$-Primavera were collected in these same three days, to measure their height $(\mathrm{mm})$ from the sheath to the insertion of the last fully expanded leaf. Plant height (variety Palha-Murcha) and dry weight (both varieties) were evaluated after 130 (Palha-Murcha) and 110 (BRS-Primavera) days of planting, using 10 plants per subplot. The collected plants were packed in paper bags, dried in a forced air circulation oven at $70{ }^{\circ} \mathrm{C}$ and weighed to obtain the plant dry weight $\left(\mathrm{kg} \mathrm{ha}^{-1}\right)$. The number of panicles in the evaluation area of the subplot $\left(2.7 \mathrm{~m}^{2}\right)$ was counted (units $\mathrm{m}^{-2}$ ) at the end of the crop cycle and its grains were removed manually, stored in paper bags and weighed in a precision scale $\left(\mathrm{kg} \mathrm{ha}^{-1}\right)$ with water content corrected to $13 \%$.

Leaf scald and brown leafspot severity were evaluated in Igarapé do Meio at the last stage of the plant cycle (110 days after emergence); these diseases have high occurrence at this stage. Leaf scald was evaluated in São Bento at the floral differentiation stage and brown leafspot at the last stage of the plant cycle (103 days after planting).

Ten leaves were randomly collected in each subplot to evaluate these two diseases, using the scale of grades of the Centro Internacional de Agricultura Tropical - CIAT (1983) considering the leaf area affected by the diseases $(0=$ absence of diseases, $1=$ below $1 \%, 3=1$ to $5 \%, 5=6$ to $25 \%$, $7=26$ to $50 \%, 9=$ above $50 \%$ ). Leaf scald severity was evaluated considering the lesion length in relation to the total area in each leaf. Grain spot severity was evaluated on 400 grains removed from eight panicles collected from each subplot, using a scale of grades considering the stained surface of the grain $(0=$ none, $1=1$ to $25 \%, 2=26$ to $50 \%$, $4=51$ to $75 \%$ ) (SILVA-LOBO et al., 2011).

The rice varieties were analyzed separately. Data were subjected to analysis of variance and regression. The models were chosen based on the biological phenomenon, significance of the regression coefficients (using probability levels of up to $10 \%$ ), t-test and coefficient of determination $\left(\mathrm{R}^{2}=\mathrm{SQ}_{\text {Regression }} / \mathrm{SQ}_{\text {Treatment }}\right)$. The means of all the 
variables of the microbiolized and non-microbiolized seeds were compared by the $\mathrm{F}$ test at $5 \%$ of probability level. The Statistical Analysis were performed using the program SAEG 9.1 (SAEG, 2007).

\section{RESULTS AND DISCUSSION}

The interaction between seed microbiolization and agro-silicon rates had no significant effect on the seedling emergence (SE, $p=0.6426$ and $p=0.2829$ ), grain yield ( $\mathrm{GY}, \mathrm{Kg} \mathrm{ha}^{-1}$, $p=0.4390$ and $p=0.4150)$, plant height (PH, $p=0.1161$ and $p=0.1160$ ), plant dry weight (PDW, $p=0.1062$ and $p=0.9999$ ), severity of brown leafspot (BL, $p=0.8469$ and $p=0.9999$ ) leaf scald (LS, $p=0.9508$ and $p=0.2218)$ and grains spot (GS, $p=0.3595$ and $p=0.9999)$ in the varieties Palha-Murcha and BRS-Primavera, and on the number of panicle (NP, $p=0.8120$ ) of the variety Palha-Murcha. Therefore, the effect of agro-silicon and seed microbiolization was assessed separately.

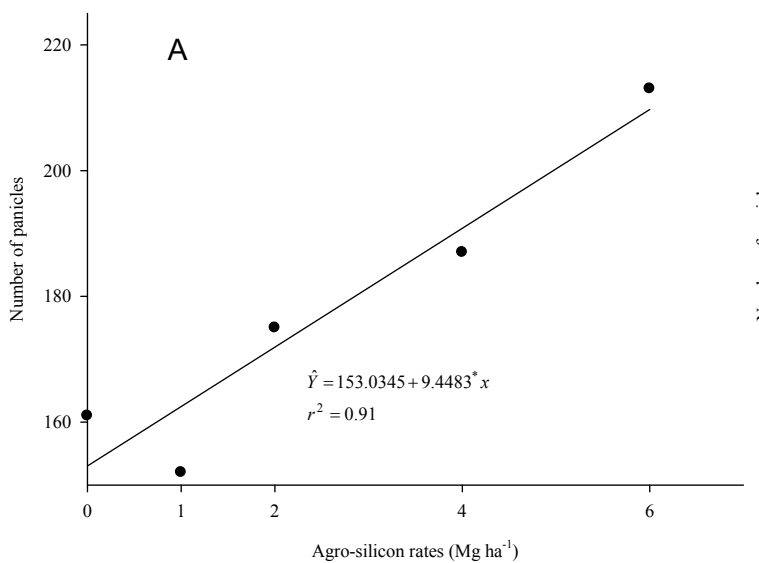

The interaction between seed microbiolization and agro-silicon rates had significant effect on the NP $(p=0.0316)$ of the variety $B R S$-Primavera, increasing linearly with increasing agro-silicon rates with microbiolized seeds (Figure $1 \mathrm{~A})$ and showed a quadratic effect with non-microbiolized seeds (Figure 1B). The NP $\left(\mathrm{F}_{1 ; 20}=6.49 ; p=0.0192\right)$ was affected by the seed microbiolization with Bacillus methylotrophicus. The highest NP was found in plants of non-microbiolized seeds (Table 1). This result may be related to permanence for 24 hours of the microbiolized seeds in the B. methylotrophicus solution, which reduced the emergence of seedlings. Similar results were found by Filippi et al. (2012), with all silicon rates reducing leaf blast severity in leaves (area under the disease progress curve - AUDPC) and panicles, and increasing the weight of one thousand grains. These authors also found a reduction of 76 and $50 \%$ of AACPD, respectively with and without microbiolized seeds, denoting the positive interaction between silicon fertilization and rhizobacteria.

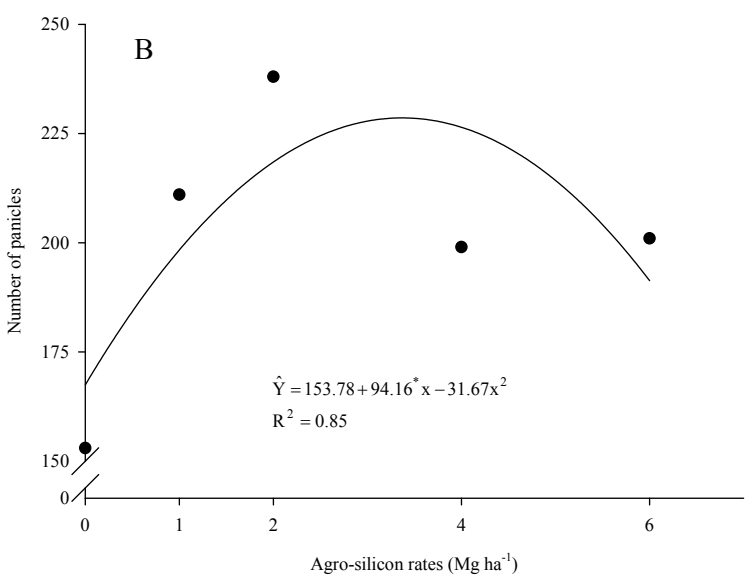

Figure 1. Number of panicles as a function of agro-silicon rates $\left(\mathrm{Mg} \mathrm{ha}^{-1}\right)$ on microbiolized (A) and non-microbiolized (B) seeds of the rice variety BRS-Primavera with Bacillus methylotrophicus, in the 2014-2015 crop season.

The height of plants $(\mathrm{PH})$ of the variety Palha-Murcha increased linearly with increasing agro-silicon rates (Figure 2), increasing $1.99 \mathrm{~cm}$ for each $\mathrm{Mg}$ of agro-silicon applied. The $\mathrm{PH}$ of the variety BRS-Primavera was not affected by the agro-silicon rates, showing mean $\mathrm{PH}$ of $18.12 \mathrm{~cm}$. The results of the improved variety (BRS-Primavera) confirm those found by Reis et al. (2008), who evaluated silicon fertilization in two rice varieties (IAC 201 and IAC 202) with aspersion irrigation and found no effect on plant height.

The agro-silicon rates had no effect on the SE, GY, PDW and NP of the variety Palha-Murcha, whose averages were $19.99 \%(\mathrm{SE}), 567.51 \mathrm{~kg} \mathrm{ha}^{-1}$ (GY), $3348 \mathrm{~kg} \mathrm{ha}^{-1}$ (PDW) and 22.4 (NP). The SE (decreasing linear effect), PDW (increasing linear effect) (Figure 3A) and GY (plateau effect) of variety BRS-Primavera were affected with increasing agro-silicon rates (Figure $3 \mathrm{~B}$ ). The model for $\mathrm{SE}$ as a function of agro-silicon rates was $\hat{Y}=21.04-0.4023^{*} x ; r^{2}=0.70$. The GY reached the plateau at $1,514.2 \mathrm{~kg} \mathrm{ha}^{-1}$, with a agro-silicon rate of $2.56 \mathrm{Mg} \mathrm{ha}{ }^{-1}$. According to the decreasing increments law, fertilizers should not be applied aiming the maximum yield, but a yield that returns the greatest profit for the farmer, i.e., the maximum economic yield. Therefore, following this principle of the law of decreasing increments when increasing a high potassium silicate rates, productivity has a tendency to not follow this increase, since the maximum economic productivity was reached (SANTOS et al., 2010). 


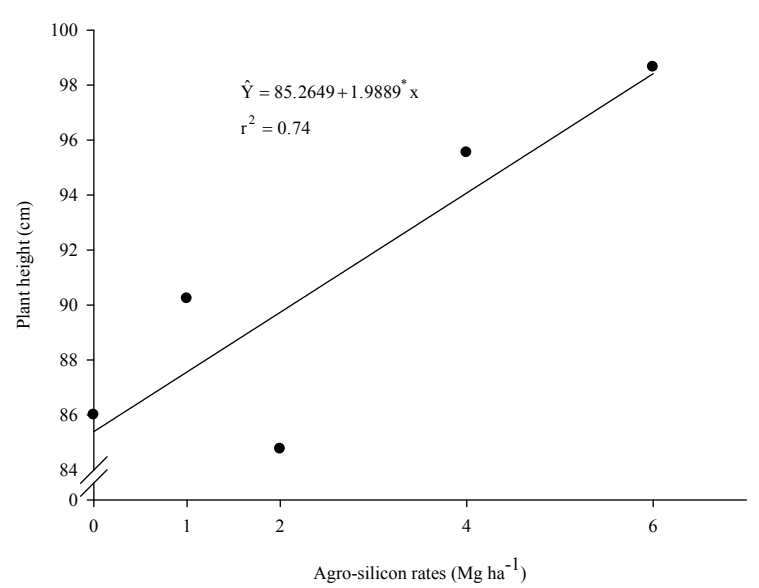

Figure 2. Plant height $(\mathrm{cm})$ of the rice variety Palha-Murcha as a function of agro-silicon rates $\left(\mathrm{Mg} \mathrm{ha}^{-1}\right)$ in the 2013-2014 crop season.
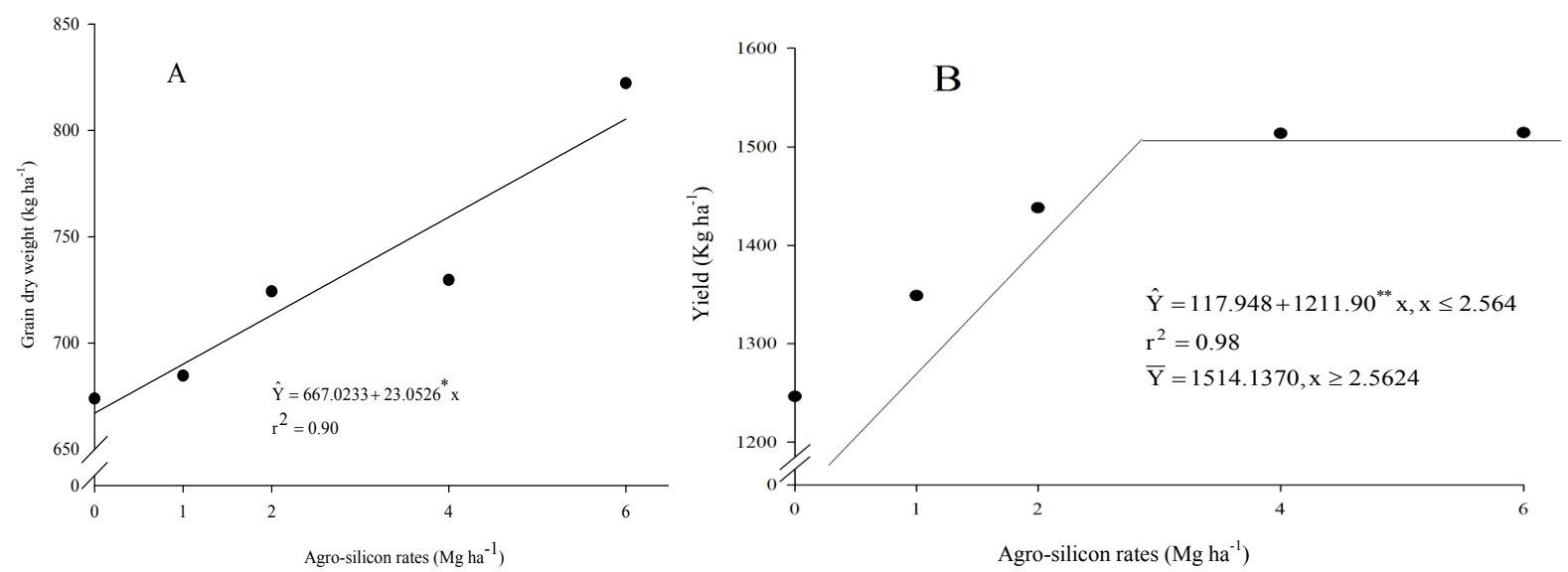

Figure 3. Grain dry weight (A) and yield (B) of the rice variety BRS-Primavera as a function of agro-silicon rates $\left(\mathrm{Mg} \mathrm{ha}^{-1}\right)$ in the 2014-2015 crop season.

The grain spot severity (Phoma sp., Drechslera oryzae, Curvularia lunata, Nigrospora oryzae, Alternaria sp., Fusarium sp.) had a decreasing quadratic effect on the variety Palha-Murcha (Figure 4A) and decreasing linear effect (Figure 4B) on the variety BRS-Primavera

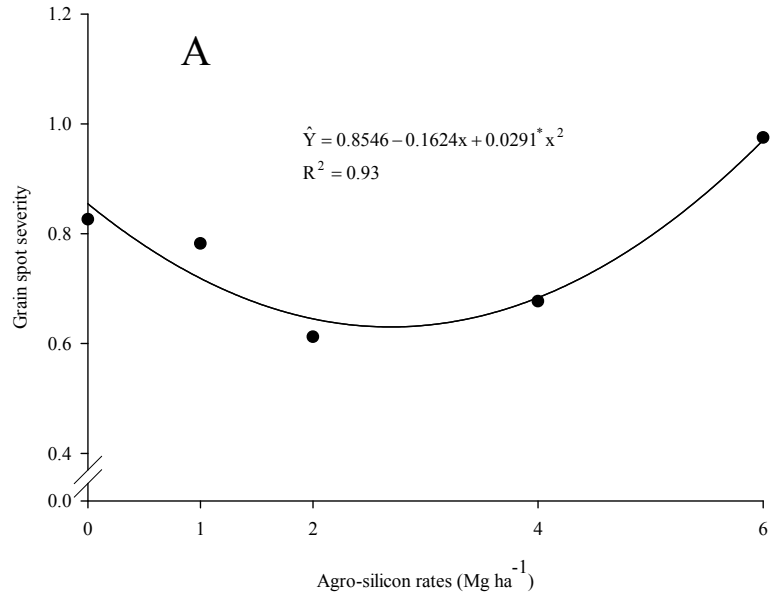

with increasing agro-silicon rates. The agro-silicon rates had no effect on the brown leafspot and leaf scald severities, which showed means of 1.17 and 1.84 (Palha-Murcha) and 1.48 and 1.87 (BRS-Primavera), respectively.

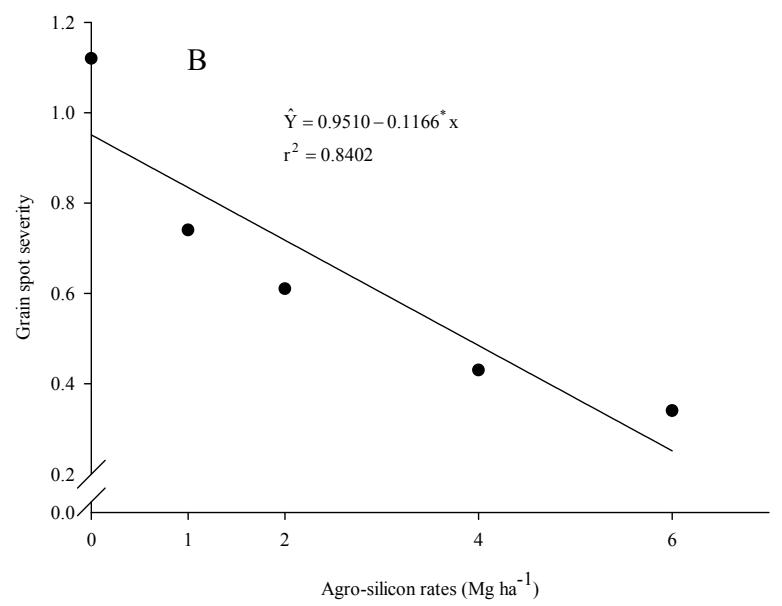

Figure 4. Grain spot severity in the rice variety Palha-Murcha (Igarapé do Meio, State of Maranhão, Brazil) and BRS-Primavera (B) as a function of agro-silicon rates $\left(\mathrm{Mg} \mathrm{ha}^{-1}\right)$ in the 2013-2014 (Palha-Murcha) and 2014-2015 (BRS-Primavera) crop season.

Rev. Caatinga, Mossoró, v. 31, n. 1, p. 126 - 134, jan. - mar., 2018 
The silicon content in the soil probably affected the agronomic performance and severity of diseases of the upland rice varieties. The soil of Igarapé do Meio (Palha-Murcha) had $5.9 \mathrm{mg} \mathrm{dm}^{-3}$ of silicon, which may have hindered the response of the plants; and the soil of São Bento (BRS-Primavera) had $1.5 \mathrm{mg} \mathrm{dm}^{-3}$ of silicon, favoring the response of the cultivar to silicon fertilization. Marchezan et al. (2004) found no response of lowland rice to silicon fertilization using calcium silicate in a soil containing 5 to $12 \mathrm{mg} \mathrm{L}^{-1}$ of silicon. On the other hand, Chagas et al. (2016) found an increase in rice grain yield with application of silicon. Mauad et al. (2013) found different plant growth for two rice cultivars fertilized with calcium silicate and dolomitic limestone; the cultivar Maravilha had higher shoot dry matter production in the anthesis and milky grain stages and the cultivar Caiapó had higher shoot dry matter production in the physiological maturation stage.

The amount of calcium applied was adequate with agro-silicon rates of 1.0, 2.0, 4.0 and 6.0 $\mathrm{Mg} \mathrm{ha}^{-1}$ combined with limestone, and sufficient to increase the rice yield of the variety Palha-Murcha. Silva and Bohnen (2003) found similar results, with no beneficial effects of silicon with adequate rates of $\mathrm{Ca}$ on the evaluated parameters. Thus, beneficial effects of silicon fertilization on upland rice should not be attributed to silicon alone, but to its wide action as corrective of acidity, which promotes better soil chemical conditions to plant development (BARBOSA FILHO; PRABHU, 2002).

The soil sandy texture was also an important factor in both locations. The sand fraction is constituted mainly by $\mathrm{SiO}_{2}$ quartz, which has low release of silicon to plants and greater drainage, favoring silicon losses by leaching. According to
Marchezan et al. (2004), soil chemical and physical composition and flood conditions affect silicon availability and plant responses. This information is confirmed by Camargo, Kondorfer and Côrrea (2002), who reported more availability of silicon to plants with increasing soil clay content.

On the other hand, the variety Palha-Murcha is not improved and it may not respond to silicon treatments due to its genetic characteristics, while the variety BRS-Primavera is from a modern group, has small plants, is indicated for planting in soils of little to moderate fertility, and is moderately resistant to brown leafspot and grain spot (EMBRAPA, 2014). The ability to absorb nutrients from the soil and nutrient demand required vary according to several factors, including the cultivar (FARIA JÚNIOR et al., 2009).

The microbiolization had no effect on the GY $\left[\left(\mathrm{F}_{1 ; 20}=0.025 ; \quad p=0.8766\right) \quad\right.$ and $\quad\left(\mathrm{F}_{1 ; 20}=0.78\right.$; $p=0.9999)], \quad$ PH $\quad\left[\left(\mathrm{F}_{1 ; 20}=2.372 ; \quad p=0.1161\right) \quad\right.$ and $\left.\left(\mathrm{F}_{1 ; 20}=2.141 ; p=0.1586\right)\right]$ (Table 1$), \mathrm{BL}$ severity $\left[\left(\mathrm{F}_{1 ; 20}=1.696 ; \quad p=0.2076\right) \quad\right.$ and $\quad\left(\mathrm{F}_{1 ; 20}=0.781\right.$; $p=0.9999)]$ and GS severity $\left[\left(\mathrm{F}_{1 ; 20}=1.614 ; p=0.2185\right)\right.$ and $\left.\left(\mathrm{F}_{1 ; 20}=1.456 ; p=0.2417\right)\right]$ of the Palha-Murcha and BRS-Primavera, respectively (Table 2).

Seed microbiolization had no effect on the SE $\left(\mathrm{F}_{1 ; 20}=2.135 ; \quad p=0.1595\right), \quad$ PDW $\quad\left(\mathrm{F}_{1 ; 20}=0.327\right.$; $p=0.5735), \mathrm{NP}\left(\mathrm{F}_{1 ; 20}=1.880 ; p=0.1855\right)$ (Table 1$)$ and LS $\left(\mathrm{F}_{1 ; 20}=1.835 ; \quad p=0.1907\right)$ of the variety Palha-Murcha (Table 2). These same variables were affected by the seed microbiolization with $B$. methylotrophicus, in the variety BRS-Primavera, with $\mathrm{SE}\left(\mathrm{F}_{1 ; 20}=33.87 ; p \leq 0.0001\right)$, PDW $\left(\mathrm{F}_{1 ; 20}=5.42\right.$; $p=0.0305)$ (Table 1$)$ and $\operatorname{LS}\left(\mathrm{F}_{1 ; 20}=4.66 ; p=0.0433\right)$ (Table 2). The rice seed microbiolization with $B$. methylotrophicus reduced the leaf scald severity in the variety BRS-Primavera by $40 \%$ (Table 2 ).

Table 1. Mean values of agronomic variables of the rice varieties Palha-Murcha and BRS-Primavera as a function of microbiolized and non-microbiolized seeds with B. methylotrophicus.

\begin{tabular}{|c|c|c|c|c|c|}
\hline \multirow{2}{*}{ Microbiolization } & \multicolumn{5}{|c|}{ Palha-Murcha } \\
\hline & SE (\%) & GY $\left(\mathrm{kg} \mathrm{ha}^{-1}\right)$ & $\mathrm{NP}\left(\right.$ unit $\mathrm{m}^{-2}$ ) & $\mathrm{PH}(\mathrm{cm})$ & PDW $\left(\mathrm{kg} \mathrm{ha}^{-1}\right)$ \\
\hline With & $31.9 \mathrm{a}$ & $564.5 \mathrm{a}$ & $57.6 \mathrm{a}$ & $92.1 \mathrm{a}$ & $3.452 .4 \mathrm{a}$ \\
\hline Without & $35.7 \mathrm{a}$ & $570.4 \mathrm{a}$ & $63.6 \mathrm{a}$ & $88.7 \mathrm{a}$ & $3.243 .6 \mathrm{a}$ \\
\hline$\overline{C V_{\text {plot }}(\%)}$ & 18.2 & 60.1 & 47.1 & 15.3 & 55.6 \\
\hline \multirow[t]{2}{*}{$\mathrm{CV}_{\text {subplot }}(\%)$} & 27.2 & 23.3 & 25.2 & M 8.5 & 39.1 \\
\hline & \multicolumn{5}{|c|}{ BRS-Primavera } \\
\hline$\overline{\text { With }}$ & $43.8 \mathrm{~b}$ & $1356.0 \mathrm{a}$ & $178.0 \mathrm{~b}$ & $21.00 \mathrm{a}$ & $759.6 \mathrm{a}$ \\
\hline Without & $56.6 \mathrm{a}$ & $1698.5 \mathrm{a}$ & $200.0 \mathrm{a}$ & $17.00 \mathrm{a}$ & $684.0 \mathrm{~b}$ \\
\hline$\overline{C V_{\text {plot }}(\%)}$ & 24.1 & 39.8 & 45.7 & 16.6 & 22.5 \\
\hline $\mathrm{CV}_{\text {subplot }}(\%)$ & 16.2 & 24.5 & 16.7 & 21.3 & 17.2 \\
\hline
\end{tabular}

Means followed by same letter in the columns do not differ by the $\mathrm{F}$ test at $5 \%$ probability. $\mathrm{SE}=$ seedling emergence, $\mathrm{GY}=$ grain yield, $\mathrm{NP}=$ number of panicles, $\mathrm{PH}=$ plant height, $\mathrm{PDW}=$ plant dry weight. 
Table 2. Severity of the diseases leaf scald (LS) (Monographella albescens Thume), brown leafspot (BL) (Helminthosporium oryzae Breda de Haan) and grain spot (GS) (Phoma sp., Drechslera oryzae, Curvularia lunata, Nigrospora oryzae, Alternaria sp., Fusarium sp.) in the rice varieties Palha-Murcha and BRS-Primavera as a function of microbiolized and non-microbiolized seeds with B. methylotrophicus.

\begin{tabular}{|c|c|c|c|c|c|c|}
\hline \multirow{2}{*}{ Microbiolization } & \multicolumn{3}{|c|}{ Palha-Murcha } & \multicolumn{3}{|c|}{ BRS-Primavera } \\
\hline & LS & $\mathrm{BL}$ & GS & $\mathrm{LS}$ & $\mathrm{BL}$ & GS \\
\hline With & $1.3 \mathrm{a}$ & $1.1 \mathrm{a}$ & $0.74 \mathrm{a}$ & $1.7 \mathrm{~b}$ & $1.5 \mathrm{a}$ & $1.3 \mathrm{a}$ \\
\hline Without & $1.4 \mathrm{a}$ & $1.0 \mathrm{a}$ & $0.79 \mathrm{a}$ & $2.1 \mathrm{a}$ & $1.5 \mathrm{a}$ & $1.3 \mathrm{a}$ \\
\hline $\mathrm{CV}_{\text {plot }}(\%)$ & 41.7 & 47.9 & 37.9 & 96.2 & 70.1 & 47.0 \\
\hline $\mathrm{CV}_{\text {subplot }}(\%)$ & 41.8 & 30.6 & 20.1 & 84.9 & 22.2 & 36.7 \\
\hline
\end{tabular}

Means followed by same letter in the columns do not differ by the $\mathrm{F}$ test at $5 \%$ probability.

According to Ludwig, Moura and Gomes (2013), Bacillus spp. did not improve the growth of rice plants, however, Souza Júnior et al. (2010) reported that a mixture of Bacillus spp. and Pseudomonas synxantha increased rice shoot dry weight and root fresh weight.

Bacillus subtilis as strains related to Bacillus amyloliquefaciens and Bacillus methylotrophicus can improve plant growth by increasing hormone levels, favoring the availability of phosphate in the soil (PANE et al., 2012). The characteristics of the varieties Palha-Murcha and BRS-Primavera were different when treated with B. methylotrophicus. Similar result was found by Ferreira, Knupp and Martin-Didonet (2014), who inoculated six rice varieties with Pseudomonas, Burkholderia and Rhizobium and found significant differences in plant height and shoot fresh weight. According to these authors, rice cultivars respond differently to inoculation with growth-promoting bacteria.

The results found in the present work are similar to those found by Ludwig et al. (2009), who found a decrease in leaf scald of $63.2 \%$ with the isolate DFs416 (Bacillus sp.). Rhizobacteria inoculation, directly or indirectly, favors the reduction of using chemical pesticides, promoting economic benefits and also ecological benefits, since such products often generate problems of environmental contamination. According to Corrêa et al. (2008), the response to biocontrol varies depending on environmental conditions, crop and pathogen population diversity, which may have several mechanisms, such as antibiosis and production of enzymes, siderophores and antibiotics, which potentiate them as bio-controllers (GERBORE et al., 2016; PANE et al., 2012). Therefore, the results found in the present work for the varieties of Palha-Murcha and BRS-Primavera confirm the instability of biocontrol under different climatic conditions, soil microbiota, cultivar and management.

Little researches are found on soil silicon fertilization combined with seed protection with microorganisms, evaluating productive performance and severity of diseases, thus, the present work contributes with new results, since the varieties showed different responses to silicon fertilization and seed microbiolization with Bacillus methylotrophicus, regarding their agronomic performance and severity of diseases.

\section{CONCLUSION}

The agro-silicon rates used affected positively the plant height of the variety Palha-Murcha, increased the seedling emergence, number of panicles and grain dry weight and yield of the variety $B R S$-Primavera, and reduce the grain spot severity in the varieties Palha-Murcha and BRS-Primavera.

The seed microbiolization with Bacillus methylotropicus reduced the leaf scald severity in the variety BRS-Primavera and did not affect the brown leafspot and grain spot severity in the two rice varieties.

\section{ACKNOWLEDGEMENTS}

The authors thank the Foundation for Research and Scientific and Technological Development of Maranhão for financial support.

\section{REFERENCES}

BARBOSA FILHO, M. P.; PRABHU, A. S. Aplicação de silicato de cálcio na cultura do arroz. Santo Antônio do Goiás: Embrapa Arroz e Feijão, 2002, 4 p. (Documento Embrapa Arroz e Feijão, 51).

CAMARGO, M. S.; KORNDORFER, G. H.; CORRÊA, G. F. Características físicas e disponibilidade de silício em solos sob vegetação de Cerrado. In: REUNIÃO BRASILEIRA DE FERTILIDADE DO SOLO E NUTRIÇÃO DE PLANTAS, 25, REUNIÃO BRASILEIRA SOBRE MICORRIZAS, 9, SIMPÓSIO BRASILEIRO DE MICROBIOLOGIA DO SOLO, 7, REUNIÃO BRASILEIRA DE BIOLOGIA DO SOLO, 4, 2002, Rio de Janeiro. Anais... Rio de Janeiro: Fertibio, 2002. 
CENTRO

INTERNACIONAL

DE AGRICULTURA TROPICAL - CIAT. Sistema de evaluación estandar para arroz. 2. ed. Cali, 1983. $61 \mathrm{p}$.

CHAGAS, R. C. S. et al. Silicon fertilization improve yield and quality of rice and pearl millet in cerrado soils. Bioscience Journal, Uberlândia, v. 32, n. 4, p. 899-907, 2016.

CORRÊA, B. O. et al. Influência da microbiolização de sementes de feijão sobre a transmissão de Colletotrichum lindemuthianum (Saac e Magn.). Revista Brasileira de Sementes, Lavras, v. 30, n. 2, p. 156-163, 2008.

CRUSCIOL, C. A. C. et al. Effects of silicon and drought stress on tuber yield and leaf biochemical characteristics in potato. Crop Science, Madison, v. 49, n. 3, p. 949-954, 2009.

EMPRESA BRASILEIRA DE PESQUISA AGROPECUÁRIA - EMBRAPA. Catalógo de cultivares de arroz. Santo Antônio de Góias, GO: Embrapa Arroz e Feijão, 2014. 11 p.

FARIA JÚNIOR, L. A. et al. Produção de matéria seca, teor e acúmulo de silício em cultivares de arroz sob doses de silício. Ciência e Agrotecnologia, Lavras, v. 33, n. 4, p. 1034-1040, 2009.

FERREIRA, E. P. B.; KNUPP, A. M.; MARTINDIDONET, C. C. G. Crescimento de cultivares de arroz (Oryza sativa L.) influenciado pela inoculação com bactérias promotoras de crescimento de plantas. Bioscience Journal, Uberlândia, v. 30, n. 3, p. 655665, 2014.

FILIPPI, M. C. C. et al. Indução de resistência e promoção de crescimento em arroz por agentes biológicos. In: VI REUNIÃO BRASILEIRA SOBRE INDUÇÃO DE RESISTÊNCIA EM PLANTAS A PATÓGENOS, 2012, Viçosa. Anais... Viçosa: Suprema Gráfica e Editora Ltda, 2012. p. 51-78.

GERBORE, J. et al. Complete Genome Sequenceof Bacillus methylotrophicus Strain B25, a Potential Plant Growth-Promoting Rhizobacterium. Genome Announcements, Washington, v. 4, n. 2, p. 1-2, 2016.

GOMES, F. B. et al. Uso do silício como indutor de resistência em batata a Myzus persicae (Sulzer) (Hemiptera: Aphididae). Neotropical Entomology, Botucatu, v. 37, n. 2, p. 185-190, 2008.

GOMES, C. F. et al. Disponibilidade de silício para a cultura do arroz, em função de fontes, tempo de incubação e classe de solo. Pesquisa Agropecuária
Tropical, Goiânia, v. 41, n. 4, p. 531-548, 2011.

GUNES, A. et al. Influence of silicon on antioxidant mechanisms and lilip peroxidation in chickpea (Cicer arietinum L.) cultivars under drought stress. Journal of Plant Interactions, Londres, v. 2, n. 2, p. 105-113, 2007.

KHUSH, G. S.; JENA, K. K. Current status and future prospects for research on blast resistance in rice (Oryza sativa L.). In: WANG, G. L.; VALENT, B. (Eds.). Advances in genetics, genomics and control of rice blast disease. China, 2008, 428 p.

LUDWIG, J.; MOURA, A. B. Controle biológico da queima-das-bainhas em arroz pela microbiolização de sementes com bactérias antagonistas. Fitopatologia Brasileira, Brasília, v. 32, n. 5, p. 381 $-386,2007$.

LUDWIG, J.; MOURA, A. B.; GOMES, C. B. (Potencial da Microbiolização de sementes de arroz com rizobactérias para o biocontrole do nematoide das galhas. Tropical Plant Pathology, Brasília, v. 38, n. 3, p. 264-268, 2013.

LUDWIG, J. et al. Microbiolização de sementes para o controle da mancha parda e da escaldadura em arroz irrigado. Tropical Plant Pathology, Brasília, v. 34, n. 5, p. 322-328, 2009.

MARCHEZAN, F. et al. Aplicação de silício em arroz irrigado: efeito nos componentes de produção. Bioscience Journal, Uberlândia, v. 20, n. 3, p. 125 $131,2004$.

MAUAD, M. et al. Acúmulo de silício na parte aérea de cultivares de arroz de terras altas afetado pela aplicação de silicato e carbonato no solo. Semina: Ciências Agrárias, Londrina, v. 34, n. 5, p. 20492060, 2013.

MENDONÇA, A. O. et al. Acúmulo de silício e compostos fenólicos na parte aérea de plantas de trigo após a adubação silicatada. Bioscience Journal, Uberlândia, v. 29, n. 5, p. 1154-1162, 2013.

NASCIMENTO, I. O. et al. Isolation, identification and in vitro evaluation of Bacillus spp. In control of Magnaporthe oryzae comparing evaluation methods. African Journal of Agricultural Research, Lagos, v. 11, n. 19 , p. 1743-1749, 2016.

REIS, M. A. et al. Aplicação de silício em arroz de terras altas irrigado por aspersão. Acta Science Agronomica, Maringá, v. 30, n. 1, p. 37-43, 2008.

PANE, C. et al. Novel strain of Bacillus isolated from compost and compost-amended soils, as biological control agents against soil-borne 
phytopathogenic fungi. Biocontrol Science

Technology, Londres, v. 22, n. 12, p. 1373-1388, 2012.

SAEG. Sistema para análises estatísticas, versão 9.1. Viçosa: UFV, 2007.

SANGSTER, A. G.; HODSON, M. J.; TUBB, H. J. Silicon deposition in higher plants. In: DATNOFF, L. E.; SNYDER, G. H.; KORNDORFER, G. H. (Eds.). Silicon in agriculture. Studies in plant science, New York, v. 8, s/n., p. 85-113, 2001.

SANTOS, A. B.; SANTIAGO, C. M. Informações técnicas para a cultura do arroz irrigado nas regiões Norte e Nordeste do Brasil. Santo Antônio de Goiás, GO: Embrapa Arroz e Feijão, 2014. 150 p. (Documento Embrapa Arroz e Feijão, 279).

SANTOS, D. S. et al. Eficiência de fontes de silício para a cultura do arroz. Enciclópedia Biosfera, Goiânia, v. 6, n. 11, p. 1-10, 2010.

SANTOS, G. R. et al. Danos causados por doenças fúngicas no arroz cultivado em várzeas no Sul do estado do Tocantins. Bragantia, Campinas, v. 70, n. 4, p. 869-875, 2011.

SILVA-LOBO, V. L. et al. Influência da adubação nitrogenada, época de plantio e aerosporos sobre a severidade da mancha de grãos em arroz de terras altas. Summa Phytopathologica, Botucatu, v. 37, n. 3, p. 110-115, 2011.

SILVA, L. S.; BOHNEN, H. Produtividade e absorção de nutrientes pelo arroz cultivado em solução nutritiva com diferentes níveis de silício e cálcio. Revista Brasileira Agrociência, Pelotas, v. 9, n. 1, p. 49-52, 2003.

SOUZA JÚNIOR, I. T. et al. Biocontrole da queimadas-bainhas e do nematoide-das-galhas e promoção de crescimento de plantas de arroz por rizobactérias. Pesquisa Agropecuária Brasileira, Brasília, v. 45, n. 11, p. 1259-1267, 2010.

TUMBARSKI, Y.; PETKOV, E.; DENKOVA, Z. Study on the influence of the cultural conditions and the composition of the culture medium on the antimicrobial activity of Bacillus methylotrophicus BM47 against some fungal phytopathogens. Journal of Global Biosciences, Washim, v. 4, n. 8, p. 29902996, 2015.

UTUMI, M. M. Sistema de produção de arroz de terras altas. 4. ed. Porto Velho, RO: Embrapa Rondônia, 2008. 33 p. 